\title{
DENDROCHRONOLOGY AND GROWTH OF Copaifera langsdorffii WOOD IN THE VEGETATIVE DYNAMICS OF THE PIRAPITINGA ECOLOGICAL STATION, STATE OF MINAS GERAIS, BRAZIL
}

\author{
Daniel Costa de Carvalho ${ }^{1}$, Marcos Gervasio Pereira ${ }^{2 *}$, João Vicente Figueiredo Latorraca ${ }^{1}$, José Henrique \\ Camargo Pace ${ }^{1}$, Leonardo Davi Silveira Augusto Baptista da Silva ${ }^{1}$, Jair Figueiredo do Carmo ${ }^{3}$ \\ ${ }^{1}$ Rural Federal University of Rio de Janeiro, Institute of Forests, Seropédica, Rio de Janeiro, Brazil - danielcostadecarvalho@ gmail.com; \\ joaolatorraca@gmail.com; josehcpace@gmail.com; leonardofloprio@ hotmail.com \\ ${ }^{2 *}$ Rural Federal University of Rio de Janeiro, Department of Soils, Seropédica, Rio de Janeiro, Brazil - mgervasiopereira01@ gmail.com \\ ${ }^{3}$ Federal University of Mato Grosso, Institute of Agricultural and Environmental Sciences, Cuiabá, Mato Grosso, Brazil - \\ carmo.jair@gmail.com
}

Received for publication: 22/12/2016 - Accepted for publication: 15/12/2017

\begin{abstract}
The aim of this study was to construct the chronology of Copaifera langsdorffii (copaíba) growth rings in order to understand the dynamics of Cerrado vegetation formations that occur in a river island in the Três Marias Hydroelectric Power Plant reservoir, state of Minas Gerais, Brazil. For this purpose, 30 copaíba trees identified in the Mata Seca Sempre-Verde phytophysiognomy at Pirapitinga Ecological Station (PES), state of Minas Gerais, were selected. Two radial samples of each tree were collected with the aid of a probe. The samples were mechanically polished for better visualization of the growth rings, which allowed their delimitation and measurement. Afterwards, the synchronization of the growth rings width was verified in order to generate a master chronological series of the species. To verify the influence of meteorological factors, Pearson correlation $(\mathrm{p}<0.5)$ was used. The results evidenced that the copaíba population from the PES presents dendrochronological potential, confirmed by the high correlation of the growth rings widths among trees. Dendrochronological analysis revealed that copaíba trees were already present before the reservoir filling, but with a lower population density than currently. In addition, it was possible to infer that the development of the phytophysiognomy of the Mata Seca Sempre-Verde began in the 1970s. The average sensitivity was sufficient to consider the species sensitive to environmental variations. Precipitation and temperature influenced positively the wood growth in the transition between climatic seasons. The results revealed information regarding the dynamics of the local vegetation and elucidated the changes that occurred in the environment in which the copaíba population is established.

Keywords: Copaíba, growth rings, meteorological factors.
\end{abstract}

\section{Resumo}

Dendrocronologia e crescimento do lenho de Copaifera langsdorffii na dinâmica vegetacional da estação ecológica Pirapitinga, Minas Gerais. O objetivo deste estudo foi construir a cronologia dos anéis de crescimento de Copaifera langsdorffii (copaíba) a fim de compreender a dinâmica das formações vegetacionais do Cerrado que ocorrem em uma ilha fluvial do reservatório da Usina Hidroelétrica de Três Marias, Minas Gerais. Para isso, foram selecionadas 30 árvores de copaíba identificadas na fitofisionomia da Mata Seca Sempre-Verde na Estação Ecológica de Pirapitinga (EEP), Minas Gerais. Foram coletadas duas amostras radiais de cada árvore com auxílio de uma sonda. As amostras passaram por polimento mecânico para melhor visualização dos anéis de crescimento, permitindo a delimitação e mensuração dos mesmos. Posteriormente, foi verificada a sincronização da largura dos anéis de crescimento para gerar uma série cronológica mestra da espécie. Para verificar a influência dos fatores meteorológicos, foi utilizada a correlação Pearson $(p<0,5)$. Os resultados evidenciaram que a população de copaíba da EEP apresenta potencial dendrocronológico, confirmado pela elevada correlação da largura dos anéis de crescimento dentre e entre árvores. As análises dendrocronológicas revelaram que as árvores de copaíba já estavam presentes antes do enchimento do reservatório, porém com menor densidade populacional que nos dias atuais. Também, foi possível inferir que o desenvolvimento da fitofisionomia Mata Seca Sempre-Verde ocorreu a partir da década de 1970. A sensibilidade média foi suficiente para a espécie ser considerada sensível às variações ambientais. Já a precipitação e temperatura influenciaram positivamente o crescimento do lenho na transição entre as estações climáticas. Os resultados revelaram informações sobre a dinâmica da vegetação local, elucidando as mudanças ocorridas no ambiente no qual a população de copaíba está estabelecida.

Palavras-chave: Copaíba, anéis de crescimento, fatores meteorológicos.

FLORESTA, Curitiba, PR, v. 48, n. 1, p. 49 - 58, jan. / marc. 2018.

Carvalho. D. C. et al.

ISSN eletrônico 1982-4688

DOI: $10.5380 /$ rf.v48 i1.49905 


\section{INTRODUCTION}

As the demand for natural resources increases, the periodic diagnosis of land use becomes a fundamental aspect to understand space organization patterns, which are rarely permanent due to the high dynamics of the natural and anthropogenic activities. Therefore, it is necessary to select specific techniques to understand the environmental organization patterns in function of these modifications (SOUTHWORT et al., 2013).

A potential technique for detecting vegetation and local landscape changes is the dendrochronological analysis (SOUTHWORT et al., 2013). Dendrochronology is a science that studies the formation of growth rings in plant species. The formation of these rings can be influenced by climatic, physical, genetic and/or anthropic events, such as precipitation, temperature, frequency of floodings, prolonged drought, soil quality, species deciduousness, and types of forest management (WORBES et al., 2003; LISI, et al., 2008; SOUTHWORT et al., 2013; LATORRACA et al., 2015; MATTOS et al., 2015; DÜNISCH; LATORRACA, 2016; FIGUEIREDO FILHO et al., 2017). Thus, growth rings can provide information on past and present environmental conditions (SOUTHWORT et al., 2013; FIGUEIREDO FILHO et al., 2017). Several authors have been using chronological signs from the wood of some tree species to elucidate the climate pattern and anthropogenic and natural events, such as avalanches, inundations, landslides, among others. Therefore, they infer changes occurred in the landscape (BUCHWAL, 2008; SASS-KLAASSEN et al., 2008; BUTLER, SAWYER, 2008; SOUTHWORT et al., 2013).

Knowing the age of the trees and the information that can be inferred from the growth rings analysis is of utmost importance for the optimization of forest use (WORBES et al., 2003; DÜNISCH; LATORRACA, 2016). However, this will only be possible through the involvement of different forestry research areas. Studying the past of the forests can provide indispensable information regarding how to use, manage and preserve this resource for the future (DÜNISCH, LATORRACA, 2016).

However, in order to perform dendrochronological assessments, it is necessary to select species that have perceptible growth rings, such as the copaíba (Copaifera langsdorffii Desf. - Fabaceae). This tree species has great ecological plasticity. It is also present in several biomes - Cerrado sensu lato, Atlantic Forest, Caatinga and Amazon rainforest - and associated ecosystems (CARVALHO, 2003). In relation to the ecological group, copaíba is classified as late secondary and climax, demanding for light and tolerant to shade. Moreover, it is considered a long-lived tree (CARVALHO, 2003). Melo Júnior et al. (2011) studied the ecological anatomy of C. langsdorffii wood distributed in different soil conditions of the South-Brazilian Cerrado. However, the authors did not discuss the relationship among growth rings, climate variables and recent environmental changes.

Based on this reasoning, a site that presents potential for dendrochronological studies for environmental analysis is the Pirapitinga Ecological Station (PES), state of Minas Gerais, Brazil, due to the construction of the Três Marias Dam in 1962, which caused significant changes in the local landscape. Some of these changes were the emergence, evolution and extinction of some Cerrado sensu lato phytophysiognomies at PES. The most noticeable change was the emergence of the Mata Seca Sempre-Verde phytophysiognomy, where savannah and grassland formations were previously established (CARVALHO et al., 2016). This Cerrado phytophysiognomy is located in lower parts of its relief. Hence, it is subject to the influence of the water table, but it has no flooding periods (CARVALHO et al., 2016). The Mata Seca Sempre-Verde of the PES presents several tree species that are representative of this phytophysiognomy; $C$. langsdorffii being one of them (GIÁCOMO et al., 2015).

Therefore, this study was based on the hypothesis that local environmental changes cause perceptible changes in the growth rings of plant species. In order to verify this hypothesis, the present study aimed to analyze mature copaíba trees from the Mata Seca Sempre-Verde of the PES through the growth rings analysis. Based on this, we intended to estimate the population age of this phytophysiognomy and verify the relation among growth rings, meteorological variables and local environmental changes.

\section{MATERIAL AND METHODS}

This study was conducted at Pirapitinga Ecological Station (PES), between the municipalities of Morada Nova de Minas and Três Marias, state of Minas Gerais, Brazil (Figure 1a). This Conservation Unit belongs to the fluvial archipelago of Ilhas das Marias, located at the Três Marias Hydroelectric Power Plant (THPP) reservoir. Due to the water level oscillation of the THPP reservoir (up to $20 \mathrm{~m}$ ), PES acquires a feature of fluvial island when the level is full and of peninsula when it is low (ICMBIO, 2013).

PES has an approximate area of 1,180 hectares and perimeter of $20 \mathrm{~km}$, with an altitude between 570 and $630 \mathrm{~m}$ above sea level. The relief of the area is predominantly slightly undulating, with an amplitude of 60m. PES predominant soil classes are Red Latosol, in which the Mata Seca Sempre-Verde and the Cerradão are established, and Inceptisol, under the Typical Cerrado and the Campo-Sujo-Seco (CARVALHO et al., 2016). The climate of 
the region was classified as Aw by the Köppen-Geiger climate classification (ALVARES et al., 2013), which is characterized by hot and humid summers and cold and dry winters.
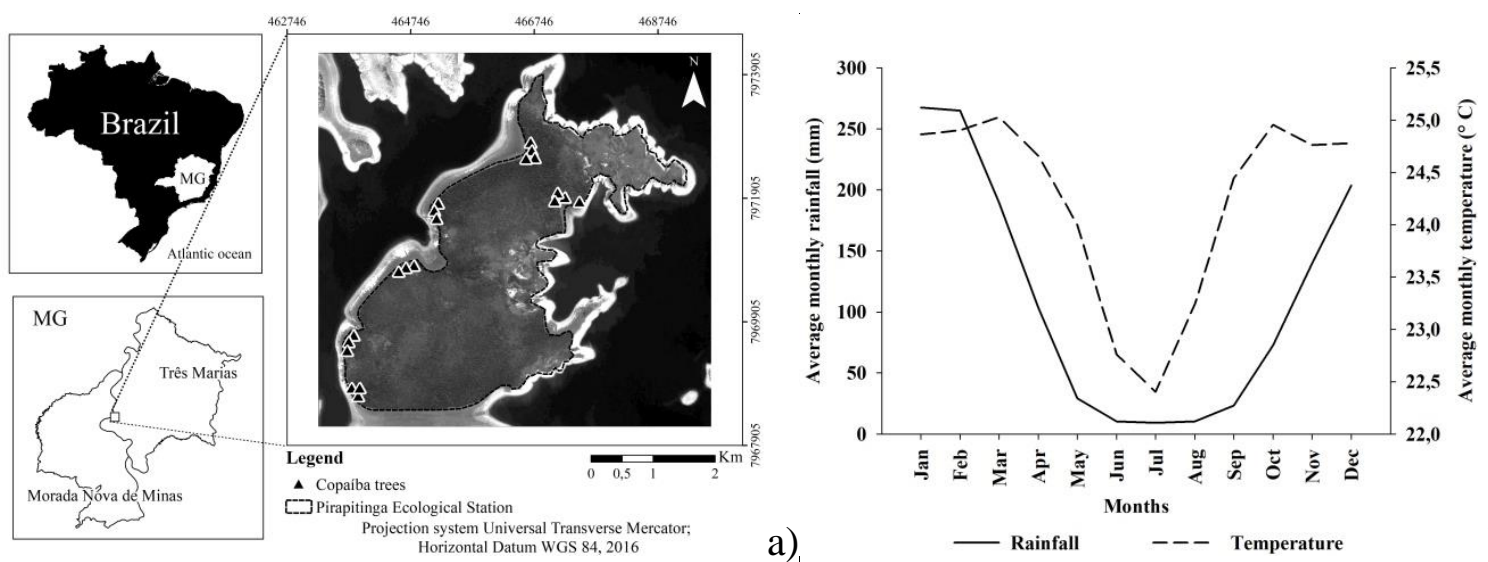

a)

- Rainfall - - Temperature

b)

Figure 1. a) Location of trees collected from Copaifera langsdorffii; b) historical climatic series (1948-2014) for the region of the Pirapitinga Ecological Station, state of Minas Gerais, Brazil.

Figura 1. a) Localização das árvores coletadas de Copaifera langsdorffii; b) série climática histórica (1948-2014) para a região da Estação Ecológica de Pirapitinga, Minas Gerais.

For dendrochronological sampling, 30 trees of $C$. langsdorffii were selected from areas of the Mata Seca Sempre-Verde of the PES (Figure 1a). This species was chosen for its representativeness in the phytophysiognomy (GIÁCOMO et al., 2015). Besides, its wood has well defined growth rings for dendrochronological assessments (MELO JÚNIOR et al., 2011). For better representativeness, mature copaíba trees of different diametric classes in perfect phytosanitary condition were randomly selected, with a diameter of $30.0 \mathrm{~cm}$ to $1.30 \mathrm{~m}$ in relation to the soil.

Two wood radial samples were collected from each tree in the bark-pith direction, with the aid of an increment borer (Pressler probe) at $1.30 \mathrm{~m}$ in relation to the soil, at the end of the wet period of the year, in February 2015. The samples were dried at room temperature and polished with a sanding sequence (between 80 and 600 grit) in order to highlight the transverse plane of the wood. All sampled trees were georeferenced and their respective circumferences at breast height (cbh) and height were recorded.

The macroscopic anatomical description was carried out according to the IAWA COMITTE classification (1989), with the aid of a stereo microscope. Identification and marking of growth rings were also carried out by using a stereo microscope. Subsequently, the samples were scanned in 1200 dpi resolution. Two rays (series) from each of the 30 copaíba sampled trees were analyzed. The growth rings width of all series were measured by using the Pro-Plus image analysis software (Copyright C 1993-2001 Media Cybernetics, Inc.). Data regarding the rings width were interpreted by the COFECHA statistical program (Version 6.00p). For the chronology construction, we used the ARSTAN program (MRWE Application Framework Copyright C 1997-2004). For the accumulated and current diameter increment, only trees of at least two series with satisfactory intercorrelation values were considered; in this case, 10 trees.

For the correlation (Pearson, $\mathrm{p}<0.05$ ) of rings formation and meteorological factors, total monthly air temperature and precipitation data from the Earth System Research Laboratory (ESRL, 2015) were compiled. The historical climatological series analyzed a period of 66 years (1948 - 2014) (Figure 1b). In order to evaluate the relationship between the growth of the copaíba trees over time, simple linear regression was applied.

\section{RESULTS}

\section{Anatomy of the wood}

After macroscopic analysis of the copaíba wood of the PES, the results pointed that it is characterized by the presence of axial parenchyma in marginal bands; visible, solitary and multiple vessels; and visible rays in the transverse plane. The growth rings are delimited by the parenchyma marginal bands, distributed at regular intervals and distanced in smaller intervals. False rings interspersed with true rings were observed. They were characterized by a smaller number of parenchyma cells ray rows and by low frequency of secretory channels within the axial parenchyma in bands (Figure 2).

FLORESTA, Curitiba, PR, v. 48, n. 1, p. 49 - 58, jan. / marc. 2018.

Carvalho. D. C. et al.

ISSN eletrônico 1982-4688

DOI: 10.5380/rf.v48 i1.49905 


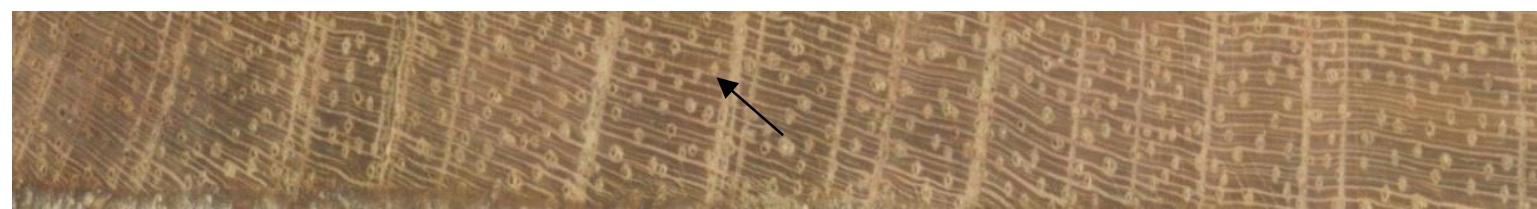

Figure 2. Cross section of the Copaifera langsdorffii wood of the Pirapitinga Ecological Station. Arrows indicate marginal parenchyma and delimit false rings.

Figura 2. Seção transversal do lenho de Copaifera langsdorffii da Estação Ecológica de Pirapitinga. Setas indicam parênquima marginal, delimitando falsos anéis.

In general, the growth ring sequence presents variations along the development of the C. langsdorffii trees established at PES. The rings begin close to the pith, and, over time, they become wider; close to the bark, they are narrower.

\section{Tree diameter growth}

The population of $C$. langsdorffii, considering the 10 trees of at least two series rays, showed minimum, average, maximum, and standard deviation values for the current diameter increment of $1.45 \mathrm{~mm}, 7.29 \mathrm{~mm}, 16.83$ $\mathrm{mm}$ and $3.06 \mathrm{~mm}$, respectively (Figure 3a). The tree number 3 obtained the highest mean diameter increment of the analyzed population. The highest value of the current diameter increment was detected in tree 4, and the lowest in tree 9 (Figure 3a). It was observed that all samples of copaiba trees have a pattern of growth (Figure 3b).

Additionally, it was noticed that the trees presented high radial growth during the first 20 years of age, indicating a possible tendency of stabilization from that period onwards (Figure 3b). It was possible to distinguish 3 groups of trees of different ages. The first, formed only by tree 2, which began its growth in 1953. This tree presented a greater trunk diameter increment between the years of 1973 and 1985. The second group, with the largest number of trees, started to grow between 1974 and 1984, reaching the greatest increment during the years of 1993 to 2000. The third group, with the youngest population, began its growth between 1987 and 1997, reaching the largest trunk increment around 2007 (Figure 3b).
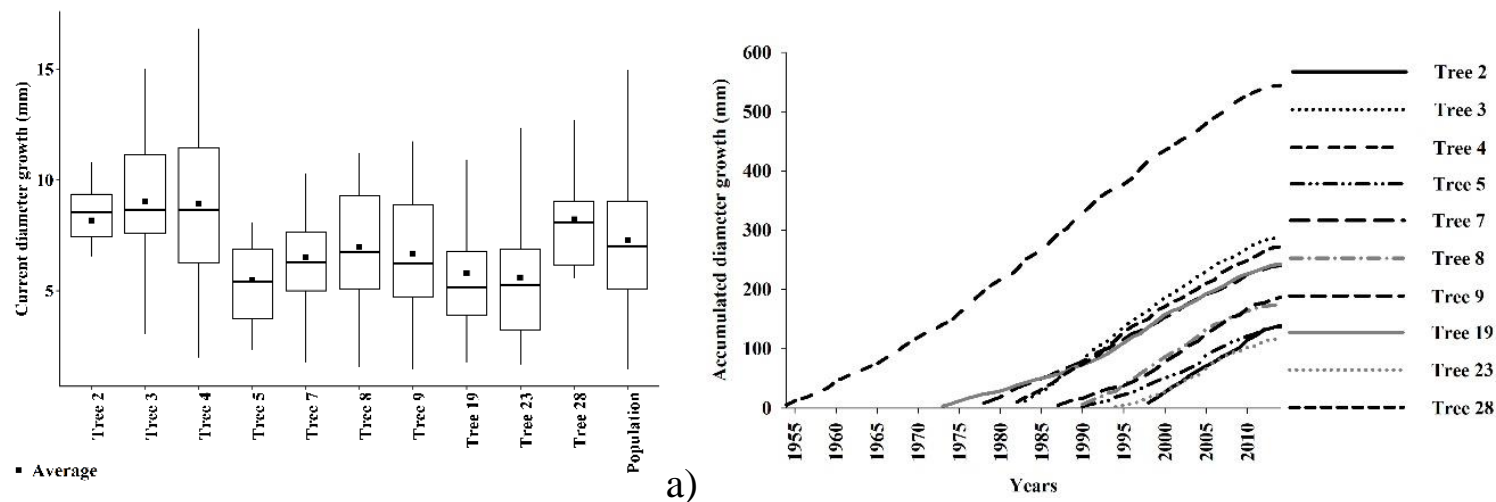

b)
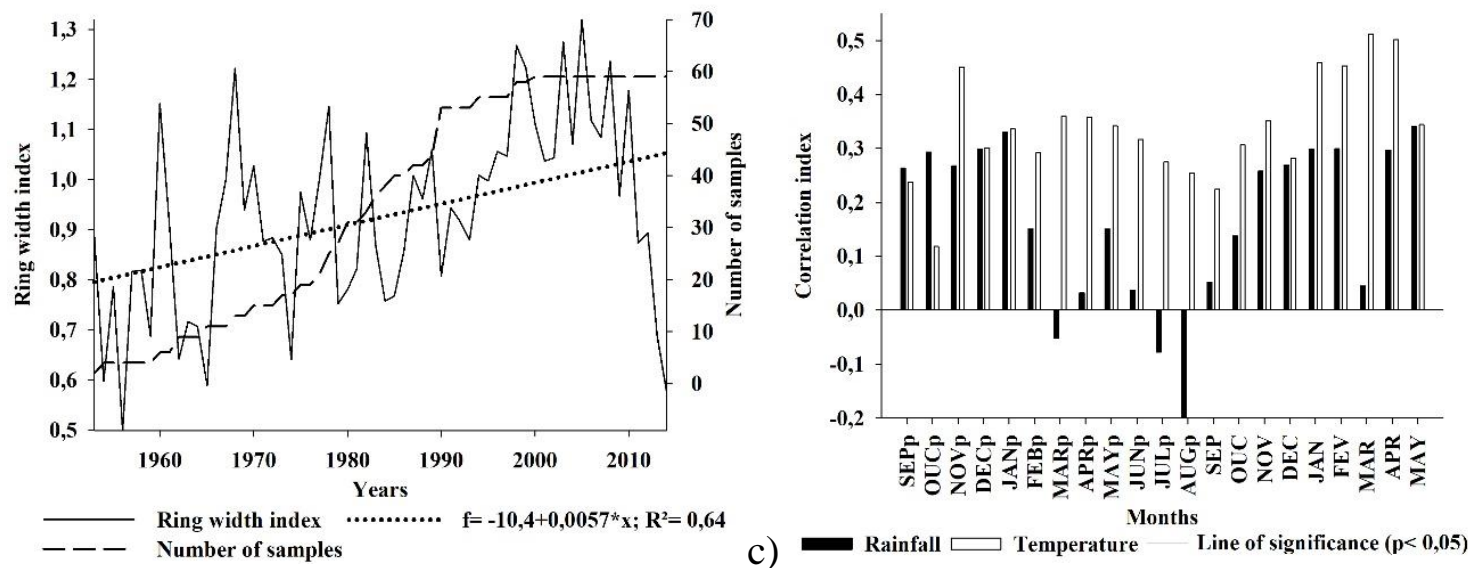
Figure 3. a) Current diameter increment of the trunk of Copaifera langsdorffii trees, with respective confidence intervals (95\%) and descriptive statistics for the population; b) Cumulative diameter increment of the trunk of Copaifera langsdorffii trees; c) Chronological series of the growth rings width index of Copaifera langsdorffii and depth of series for the set of trees; $d)$ Pearson correlation $(\mathrm{p}<0.05)$ of the main series of the growth rings index with precipitation and temperature of the Pirapitinga Ecological Station, Minas Gerais.

Figura 3. a) Incremento diametral corrente do tronco das árvores de Copaifera langsdorffii, com os respectivos intervalos de confiança $(95 \%)$ e estatística descritiva para a população; b) Incremento diametral acumulado do tronco das árvores de Copaifera langsdorffii; c) Série cronológica do Índice da largura dos anéis de crescimento do lenho de Copaifera langsdorffii e profundidade de série para o conjunto de árvores; d) Correlação de Pearson $(\mathrm{p}<0,05)$ da série mestra do índice dos anéis de crescimento com precipitação e temperatura da Estação Ecológica de Pirapitinga, Minas Gerais.

\section{Dendrochronology}

The correlation of annual tree increment data, obtained through the software COFECHA, showed synchronization of the chronological series of 19 trees among the 30 studied (63\%). These trees showed a variation in the number of growth rings - between 15 and 62 rings. The mean age of the 19 trees, with satisfactory synchronization, was 35 years (Table 1).

Table 1. Synchronization quality of chronological series of Copaifera langsdorffii trees from the Pirapitinga Ecological Station, state of Minas Gerais, Brazil.

Tabela 1. Qualidade da sincronização das séries cronológicas das árvores de Copaifera langsdorffii da Estação Ecológica de Pirapitinga, Minas Gerais.

\begin{tabular}{lcccc}
\hline $\begin{array}{c}\boldsymbol{C} \text {. } \\
\text { langsdorffii }\end{array}$ & $\begin{array}{c}\text { Number of } \\
\text { series }\end{array}$ & $\begin{array}{c}\text { Chronological } \\
\text { extension/years }\end{array}$ & $\begin{array}{c}\text { Intercorrelation for } \\
\text { master series } \mathbf{\%})\end{array}$ & Sensitivity \\
\hline Tree 1 & 1 & $2000-2014(15)$ & 46 & 35 \\
Tree 2 & 3 & $1998-2014(17)$ & 69 & 34 \\
Tree 3 & 3 & $1983-2014(17)$ & 63 & 33 \\
Tree 4 & 2 & $1954-2014(61)$ & 60 & 42 \\
Tree 5 & 3 & $1990-2014(25)$ & 58 & 39 \\
Tree 7 & 2 & $1978-2014(37)$ & 52 & 45 \\
Tree 8 & 2 & $1990-2014(25)$ & 72 & 45 \\
Tree 9 & 2 & $1987-2014(28)$ & 59 & 32 \\
Tree 11 & 1 & $1970-2014(45)$ & 54 & 44 \\
Tree 12 & 1 & $1990-2014(25)$ & 70 & 46 \\
Tree 16 & 1 & $1962-2014(53)$ & 64 & 36 \\
Tree 17 & 1 & $1953-2014(62)$ & 55 & 36 \\
Tree 19 & 2 & $1973-2014(42)$ & 54 & 35 \\
Tree 22 & 1 & $1989-2014(26)$ & 60 & 45 \\
Tree 23 & 2 & $1994-2014(21)$ & 56 & 37 \\
Tree 25 & 1 & $1965-2014(50)$ & 55 & 36 \\
Tree 27 & 1 & $1980-2014(35)$ & 57 & 34 \\
Tree 28 & 2 & $1982-2014(33)$ & 65 & 55 \\
Tree 30 & 1 & $1975-2014(40)$ & 55 & \\
\hline
\end{tabular}

All the analyzed trees presented satisfactory intercorrelation values (Table 1), making it possible to construct a general and representative chronological series for the studied region. The chronological series were significantly positive $\left(\mathrm{p}<0.05, \mathrm{R}^{2}=0.64\right)$ (Figure $3 \mathrm{c}$ ). Also, a larger number of samples with lower age were observed (Figure $3 \mathrm{c}$ ). The mean chronology presented a high correlation ( 0.60 to 0.99 significance), being above the critical one (0.32). The mean sensitivity considered was 0.41 , regarding all copaiba trees analyzed (Table 1$)$.

\section{Correlation of Copaifera langsdorffii chronology with meteorological factors}

The monthly temperature mean of the PES region, especially in the warmer months, significantly favors ( $p<0.05)$ the growth of the wood. This occurred both in the current year and in the previous year. Precipitation was also significant, favoring growth in the wetter months (Figures $1 \mathrm{~b}$ and $3 \mathrm{~d}$ ). 


\section{DISCUSSION}

\section{Anatomy of the wood}

The size variations of the rings may be related to the species' sensitivity to environmental constraints of the study area. Alves and Angyalossy-Alfonso (2000) argue that narrow growth rings near the marrow refer to the initial development period of the tree, which presents a slower growth due to competition with other plants. The wider growth rings are formed in the intermediate development stage, when the tree has a higher growth rate compared to the other stages. However, the narrow growth rings close to the bark may indicate the beginning of the senility period of the trees.

As for the formation of false rings in tropical species, several factors may influence their development, such as climatic seasonality (ALVES; ANGYALOSSY-ALFONSO, 2000) and soil conditions (MELO JUNIOR et al., 2011). Alves and Angyalossy-Alfonso (2000) determined that climatic seasonality during the year should be the main factor that affects the cambial activity of the Brazilian tree species, causing the development of true and/or false growth rings. This characteristic was observed in $48 \%$ of the species studied by the authors. Since PES has a well defined climatic seasonality (Figure 1b) (ICMBIO, 2013), any change in this climatic pattern may have led to the formation of false rings. Thus, the anatomy of the copaíba growth rings reveal important climatic information of the environment in which the trees are established.

In the study by Melo Junior et al. (2011) about the ecological anatomy of $C$. langsdorffi, which is established in different soil types of the Paraná cerrado, the academics pointed out that soil conditions were the main factors in the development of false rings for this species. The authors explain that the trees present a higher frequency of false rings in sandy soils (Neosols), which have a low water retention capacity, than those that grow in soils with a clayey texture (Latosols) that present a higher retention of water. This was also observed in the present study.

Although $C$. langsdorffii trees from the PES are established in Latossolo near the border, this soil can remain dry for months due to prolonged dry periods. In addition, drought also causes a drop in the water levels of the THPP reservoir (ICMBIO, 2013). Consequently, the water supply to C. langsdorffii trees is further reduced. With this in mind, it is reasonable to assume that soil water supply was the most important soil factor for the formation of false rings of $C$. langsdorffii trees established at PES.

\section{Tree diameter growth}

The distinction of tree groups with different ages and similar patterns of growth is corroborated by Latorraca et al. (2015). These authors also verified 3 groups of different ages and high radial growth during the first 20 years of development of Schizolobium parahyba trees in the Tinguá Biological Reserve, Rio de Janeiro.

The age determination of the trees provides information on the establishment and development of the phytophysiognomy of the Mata Seca Sempre-Verde and the PES landscape. The detection of an arboreal individual with more advanced age refers to the period before the filling of the THPP dam, before the formation of this phytophysiognomy. In the study by Carvalho et al. (2016) about the vegetation dynamics of the PES from orbital images, the academics found that the Mata Seca Sempre-Verde was consolidated in the 70s in areas where, originally, a typical Cerrado phytophysiognomy was established. In a study about the vegetation of the PES, Giácomo et al. $(2013,2015)$ revealed that, in addition to the high frequency of $C$. langsdorffii individuals in the Mata Seca Sempre-Verde, this species also occurs in other savannas vegetation, such as the Typical Cerrado and Campo Sujo Seco, but in a phytosociological positions less representative. In view of these assertions, it is reasonable to assume that the oldest individuals of $C$. langsdorffii present in the phytophysiognomy of the Mata Seca Sempre-Verde began their development in the Typical Cerrado phytophysiognomy of the PES.

The higher diameter increment observed in the pattern of the oldest copaiba tree (tree 4), even in the early development period, may be an indicative of the establishment of this tree in a more open arboreal canopy physiognomy, such as the Typical Cerrado of the PES. The Typical Cerrado presents less competition for luminosity, water and nutrients among the trees, since it is an open canopy vegetation. On the other hand, the younger groups of the PES copaíba population have lower growth rates, probably because they are developing in the Mata Seca Sempre-Verde understory, therefore competing for environmental resources with other species. This pattern was also observed by other authors, who correlate the tree development phase with the forest layer in which the tree is established (ALVES, ANGYALOSSY-ALFONSO, 2000, LATORRACA et al., 2015, FIGUEIREDO FILHO et al., 2017).

According to WORBES et al. (2003), canopy and emergent trees present higher values of growth rate when mature, since they have the crown more exposed to light than regenerating trees of the understory do. Considering the aforementioned discussion, it is presumed that the oldest trees of the copaiba population of the PES were already mature during the transition period from a sparser phytophysiognomy (Cerrado Típico) to a 
denser one, such as the Sempre-Verde Mata Seca. Meanwhile, the youngest groups of this species originated in the midst of an already established forest formation of Sempre-Verde Mata Seca.

\section{Dendrochronology}

Radial trees and series with low correlation were removed from the processing for synchronization of the chronological series, a common process for tropical species, as observed by Dünisch et al. (2003). Analyzing the 19 trees that presented satisfactory intercorrelation values, the mean chronology showed a high correlation, which allowed for a good adaptation amongst the series of growth rings. These results demonstrated that the $C$. langsdorffii trees located at PES are possible to be cross-dated and that most of them retain a common sign for the population of the species.

The mean sensitivity (0.41) was sufficient to classify the $C$. langsdorffii population present in the Mata Seca Sempre-Verde of the PES as sensitive to environmental factors. According to Fritz (1976), in order to be considered sensitive to environmental conditions, trees of the population must have a mean sensitivity value equal to or higher than 0.40. Latorraca et al. (2015) and Dünisch and Latorraca (2016), on their turn, argue that the formation of false growth rings is associated with the fact that these species are sensitive to environmental conditioning factors. Therefore, $C$. langsdorffii population of the PES confirmed to be influenced by environmental factors due to the presence of false growth rings, mentioned in the beginning of the discussion.

The evaluation of the width index of growth rings of the $C$. langsdorffii population provided information on the development of the phytophysiognomy of the Mata Seca Sempre-Verde over time. The chronological series showed to be significantly positive, i. e., the copaíba population has been showing a rising tendency over time (Figure 3c). This fact may be related to the location of the population at PES. Copaíbas are often located near the edges of the PES, where they are favored with a seasonal water supply from the water table due to the filling of the dam (ICMBIO, 2013; Giácomo et al., 2015).

The highest number of samples with lower ages (Figure 3c) corroborates the pattern found by Latorraca et al. (2015), who verified a larger number of trees sampled in younger classes. Such pattern concludes that these populations have been producing new seedlings over time, and these are managing to establish and develop themselves in the study area. The mentioned results suggest that the copaíba population of the PES has enough trees to guarantee the species' perpetuation over time in the physiognomy of Mata Seca Sempre-Verde of the PES.

The mean age of the $C$. langsdorffii trees at PES (Table 1) reinforces the assertions verified by Carvalho et al. (2016). The authors confirmed the beginning of the establishment of Mata Seca Sempre-Verde at PES in the 1970s. Therefore, the establishment of copaíba trees in this type of forest began around 1978.

It was also possible to observe, in the chronological series, the formation of narrow growth rings beginning in 2007, coinciding with the period of intense occurrence of the El Niño event (Figure 3c). Gebrekirstos et al. (2008) explain that, in addition to being influenced by rainfall and temperature, trees can also respond to larger scale events, such as the El Niño. According to information obtained at the National Institute of Space Research, as of 2007, the El Niño phenomenon caused higher temperatures and less rainfall in the Center-West region of Brazil (ALVES et al., 2009), which may have decreased the water supply to the studied region as a consequence. By monitoring the diameter of the trunk of tropical species, Gebrekirstos et al. (2008) also demonstrated that, during periods of drought, the tissue growth is reduced or null, strengthening the relationship between water stress, exchange rate activity and cell distension.

\section{Correlation of Copaifera langsdorffii chronology and meteorological factors}

The trees of $C$. langsdorffii of the PES presented layers of growth influenced by the variation of meteorological factors. The significant monthly mean temperature in hot and rainy months, both in the current and in previous years (Figure 3d), corroborates the same pattern found by Latorraca et al. (2015) in the formation of the growth rings of Schizolobium parahyba, established in Ombrophilous Forest. Therefore, as shown in Latorraca et al. (2015), the analysis of the weather conditions of the place at issue allowed to determine that the temperature exerts an important influence on the formation of growth layers (Figure 3d).

The correlation between copaíba growth and precipitation at PES indicates that, in this case, the increase of rainfalls in the summer and during the transition of seasons favor the growth rate of this species. A number of authors confirm this analysis, concluding that precipitation is the main factor that influences the growth of trees (FRITTS, 1976; WORBES et al., 2003; DÜNISCH et al., 2003; BRIENEN; ZUIDEMA, 2005; GEBREKIRSTOS et al., 2008; SASS-KLAASSEN et al., 2008; MELO JÚNIOR et al., 2011; LATORRACA et al., 2015; MATTOS et al., 2015). Additionally, a significant correlation was detected between the growth of the rings and the precipitation in the transition from the dry season to the wet season in the current and in the previous year. This situation is corroborated by Dünisch et al. (2003) and Brienen and Zuidema (2005), who reported the influence of precipitation on the transient periods of the seasons.

FLORESTA, Curitiba, PR, v. 48, n. 1, p. 49 - 58, jan. / marc. 2018.

Carvalho. D. C. et al.

ISSN eletrônico 1982-4688

DOI: 10.5380/rf.v48 i1.49905 
Hence, C. langsdorffii exists in several Brazilian biomes and phytophysiognomies, which allows the species to adapt to different temperature and rainfall conditions (CARVALHO, 2003). For the PES, a higher growth of the copaíbas was verified during months of higher temperature and precipitation. This growth may be closely related to their adaptation to both humid and xeric environments at certain times of the year (Figure $3 \mathrm{~d}$ ). (CARVALHO, 2003; MELO JÚNIOR et al., 2011).

\section{CONCLUSION}

- Copaifera langsdorffii trees belonging to PES indicated dendrochronological potential. This fact was confirmed by the high correlation of the width of growth rings between and amongst the sampled trees.

- The formation of three distinct groups of $C$. langsdorffii trees with different ages and with a similar pattern of growth was verified. Each group revealed information on the vegetation dynamics of the PES.

- Dendrochronological analysis demonstrated that $C$. langsdorffii trees were already present before the reservoir filling, although with lower population density when compared to nowadays. In addition, it was possible to infer that the development of the phytophysiognomy of the Mata Seca Sempre-Verde began in the 1970s.

- The mean sensitivity showed that the formation of the growth rings of the copaíba population established at PES is influenced by environmental conditions. Meteorological factors favored the growth of wood in the hottest and most humid seasons of the year.

\section{ACKNOWLEDGEMENTS}

To the Chico Mendes Institute for Biodiversity Conservation and the Pirapitinga Ecological Station.

\section{REFERENCES}

AlVARES, C. A.; STAPE, J. L.; SENTElhas, P. C.; GONÇAlVES, J. L. M.; SPAROVEK, G. Köppen’s climate classification map for Brazil. Meteorologische Zeitschrift, Stuttgart, v. 22, n. 6, p. 711 - 728, 2013.

ALVES, E. S.; ANGYALOSSY-ALFONSO, V. Ecological trends in the wood anatomy of some Brazilian species. I: growth rings and vessels. IAWA Journal, Leiden, v. 21, p. 3 - 30, 2000.

ALVES, L. M.; COELHO, C. A. S.; MELO, A. B. C.; PESQUER, J. F. Condições climáticas observadas no Brasil em 2009. Disponível em: <http://clima1.cptec.inpe.br/ rclima1/pdf/Sintese_Climatica_2009.pdf>. Acesso em: 15 ago. 2016.

BRIENEN, R. J. W.; ZUIDEMA, P. A. Relating tree growth to rainfall in Bolivian rain forests: a test for six species using tree ring analysis. Oecologia, Berlim, v.146, n.1, p.1 - 12, 2005.

BUTLER, D. R; SAWYER, C. F. Dendrogeomorphology and high-magnitude snow avalanches: a review and case study. Natural Hazards Earth System Sciences, Berlim, v. 8, 303 - 309, 2008.

BUCHWAL, A. Dendrogeomorphological records of trail erosion. Tree Ring in Archaeology, Climatology and Ecology, Bialowieza, v. 7, p. 166 - 170, 2008.

CARVAlHO, D. C.; PESSOA, M. M. L.; PEREIRA, M. G.; DELGADO, R. C. Evolution of Cerrado vegetal cover on a river island based on orbital imaging data. Revista Engenharia Agrícola, Jaboticabal, v. 36, n. 6, p. 1186 - 1197, 2016

CARVALHO, P. E. R. Espécies arbóreas brasileiras. Colombo: EMBRAPA, v. 1. 2003, 1039 p.

DÜNISCH, O.; MONTÓIA, V. R.; BAUCH, J. Dendroecological investigations on Swietenia macrophylla King and Cedrela odorata L. (Meliaceae) in the central Amazon. Trees, Berlim, v. 17, p. 244 - 250, 2003.

DÜNISCH, O.; LATORRACA, J. V. F. Impact of site conditions changes on the tree ring records suitability as climate proxies in the brazilian amazon. Floresta e Ambiente, Seropédica, v. 23, n. 2, p. 258 - 269, 2016.

EARTH SYSTEM RESEARCH LABORATORY - ESRL. Seasonal mean time series from the NCEP Reanalysis Dataset. Disponível em: < http://www.esrl.noaa.gov/>. Acesso em: 15 mar. 2015.

FIGUEIREDO FILHO, A.; RETSLAFF, F. S.; RETSLAFF, F S.; LONGHI-SANTOS, T.; STEPKA, T. F. Crescimento e idade de espécies nativas regenerantes sob plantio de Araucaria angustifolia no Paraná. Floresta e Ambiente, Seropédica, v. 24, n. 1, p. 1 - 9, 2017. 
FRITTS, H. C. Tree rings and climate. New York: Academic Press, 1976, 567 p.

GEBREKIRSTOS, A.; MITLO HNER, R.; TEKETAY, D.; WORBES, M. Climate growth relationships of the dominant tree species from semi-arid savanna woodland in Ethiopia. Trees, Berlim, v. 22, p. 631 - 641, 2008.

GiÁCOMO, R. G.; CARvalho, D. C.; PEREIRA, M. G.; SOUZA, A. B.; GAUI, T. D. Florística e fitossociologia em áreas de Campo Sujo e Cerrado sensu stricto na Estação Ecológica de Pirapitinga - MG. Ciência Florestal, Santa Maria, v. 23, n. 1, p. 29 - 43, 2013.

GiÁCOMO, R. G.; PEREIRA, M. G.; CARVAlHO, D. C.; MEDEIROS, V. S.; GAUI, T. D. Florística e fitossociologia em áreas de Cerradão e Mata Mesofítica na Estação Ecológica de Pirapitinga, MG. Floresta e Ambiente, Seropédica, v. 22, n. 3, p. 287 - 298, 2015.

IAWA COMMITTEE. IAWA list of microscopic features for hardwood identification. IAWA Bull. n. s., v. 10, n. 3, p. 219 - 332, 1989.

INSTITUTO CHICO MENDES DE CONSERVAÇÃO DA BIODIVERSIDADE - ICMBIO. Plano de Manejo da Estação Ecológica de Pirapitinga. Brasília: Ministério do Meio Ambiente, 2013, 216 p. Disponível em: < http:// http://www.icmbio.gov.br/>. Acesso em: 13 mar. 2014.

LATORRACA, J. V. F.; SOUZA, M. T.; SILVA, L. D. S. A. B.; RAMOS, L. M. A. Dendrocronologia de árvores de Schizolobium parahyba (Vell.) S. F. Blake de ocorrência na Rebio Tinguá-RJ. Revista Árvore, Viçosa, v. 39, n. 2, p. 385 - 394, 2015.

LISI, C. S.; TOMAZELLO-FILHO, M.; BOTOSSO, P. C.; ROIG, F. A.; MARIA, V. R. B., FERREIRA-FEDELE, L. \& VOIGT, A. R. A. Tree-ring formation, radial increment periodicity and phenology of tree species from a seasonal semi-deciduous forest in southeast Brazil. IAWA Journal, Leiden, v. 29, p. 189 - 207, 2008.

MATTOS, P. P.; BRAZ, E. M.; DOMENE, V. D.; SAMPAIO, E. V. S. B.; GASSON, P.; PAREYN, F. G. C.; ALVAREZ, I. A.; BARACAT, A.; ARAÚJO, E. L. Climate-tree growth relationships of mimosa tenuiflora in seasonally dry tropical forest, Brazil. Cerne, Lavras, v. 21, n. 1, p. 141 - 149, 2015.

MELO JÚNIOR, J. C. F.; CECCANTINI, G.; BONA, C. Anatomia ecológica do lenho de Copaifera langsdorffii Desf. (Leguminosae) distribuída em diferentes condições edáficas do cerrado sul-brasileiro. Iheringia, Porto Alegre, v. 66, n. 2, p. 189 - 200, 2011.

SASS-KLAASSEN, U.; COURALET, C.; SAHLE, Y.; STERCK, F. J. Juniper from Ethiopia contains a largescale precipitation signal. International Journal of Plant Sciences, Chicago, v. 169, p. 1057 - 1065, 2008.

SOUTHWORT, J.; RIG, L.; GIBBE, C.; WAYLE, P.; ZH, L.; MCCARRAGHE, S.; LIN, C. Integrating dendrochronology, climate and satellite remote sensing to better understand savanna landscape dynamics in the Okavango Delta, Botswana. Land, Basel, v. 2, p. 637 - 655, 2013.

WORBES, M.; STASCHEL, R.; ROLOFF, A.; JUNK, W. M. Tree rings analysis reveals age structure, dynamics an wood production of a natural forest stand in Camerron. Forest Ecology and Management, Amsterdam, v. 173, p. $105-123,2003$.

FLORESTA, Curitiba, PR, v. 48, n. 1, p. 49 - 58, jan. / marc. 2018.

Carvalho. D. C. et al.

ISSN eletrônico 1982-4688

DOI: $10.5380 /$ rf.v48 i1.49905 